\title{
Strategic Guidelines For Responding To Consumer BoycotTs
}

\author{
Dennis E. Garrett \\ College of Business Administration \\ University of Oklahoma \\ Norman, Oklahoma
}

\section{Introduction}

Although consumer boycotts have been used as a protest vehicle for centuries [18], the past decade has proven to be an era of exceptional boycott activity. The frequency of boycott usage has increased in recent years [11], and boycotts are now being used by protest groups from both ends of the political spectrum [13]. For example, liberals have recently used boycotts to protest the inclusion of meat products on restaurants' menus, the purchasing of coffee beans from allegedly repressive foreign governments, the marketing of war toys, and the manufacture of nuclear weapons components. To advance their causes, conservatives have employed boycotts recently to protest the allegedly pro-abortion content of magazines, the sexual and violent programming on television, the staging of a play satirizing Catholicism, and the sale of adult magazines in convenience stores.

What many business managers fail to realize is that almost any business can be the target of a boycott. The following well-known companies have all been the targets of boycotts during the 1980's: American Broadcasting Company, Anheuser-Busch, Burger King, Chicago Sun-Times Newspaper, Coca-Cola, Coors Brewing, Dow Chemical, Folger's Coffee, General Electric, General Foods, Hasbro Industries, Macmillan Publishing, Marriott Hotels, McDonalds, Mellon Bank, National Broadcasting Company, Nestle, Scott Paper, SmithKline Beckman Pharmaceuticals, Southland Corporation, and Union Carbide. In addition, consumer boycotts have also been directed at many smaller businesses that operate on a local or regional basis.

\section{Literature Review}

Consumer boycotts have received attention in a variety of academic disciplines, including sociology ([4], [14], [17], [23], [24]), consumer affairs ([8], $[10],[20])$, psychology $[19]$, and economics $([5],[26])$. The bulk of this research has focused on explaining why consumers choose to support a boycott. These scholars have hypothesized that a consumer's decision to support a boycott is dependent on factors such as the consumer's general attitude toward social

Journal of Business Strategies, Volume 4, Number 2 (Fall 1987) 
protest actions, the consumer's attitude toward the specific issue involved in the boycott, the cost to the consumer to participate in the boycott, the social pressure placed upon the consumer to participate, and the consumer's perception of the credibility of the boycott's leaders.

More recently, some research has considered the strategic actions employed by boycotting groups to maximize the effectiveness of their boycotts [12]. Also, some attention has been directed at the recent Nestles boycott in which a coalition of groups protested the company's marketing of infant formula in Third World countries [25].

One critical area that previous research has generally neglected is the strategic actions that the targets of boycotts should utilize to protect their interests. The previous research, with its emphasis on the boycotting groups' perspective, has failed to evaluate the position of the targets of boycotts. The only exception is a recent article in which a Nestle official described his company's handling of the baby formula dispute [21]. No prior research has sought to interview a broad range of corporate managers who have experienced the effects of boycotts directed at their organizations. As a result, little is known about how corporate managers have attempted to respond when their organizations have been the targets of boycotts.

This paucity of research is unfortunate because much has been written lately about the need for corporate executives to manage effectively their relevant environments $([16],[30])$. A consumer boycott is clearly an environmental force that deserves attention. Corporate managers who fail to respond in an appropriate manner to consumer boycotts may jeopardize the viability of their organization's disputed business practices and thereby adversely affect organizational productivity.

\section{Purpose}

Because boycotts are being increasingly used for a variety of liberal and conservative causes against a broad range of national and local businesses, business managers must be prepared to respond if they are suddenly confronted with a consumer boycott. The purpose of this article is to suggest strategic guidelines that business managers could utilize to respond effectively and efficiently when their organization becomes the target of a consumer boycott.

\section{Conceptual Framework}

Although the specific subject of managerial strategies for responding to consumer boycotts has not been extensively studied, the broad subject of how business managers should respond to environmental trauma has been studied from three related perspectives-the consumerism perspective, the consumer information processing perspective, and the crisis management perspective.

The consumerism perspective has considered what stance managers should adopt when consumers, whether acting individually or as organized pressure 
groups, complain about or seek to influence the operations of a business. Recent research in the consumerism area has suggested that conflict is often exacerbated by the differing perceptions held by managers and consumers ([9], [27]), effective communications is crucial to the resolution of consumer complaining [28], and managers may adopt either a proactive or reactive posture in response to consumerism pressure [2].

The consumer information processing perspective has attempted to utilize information processing theory [1] to evaluate the optimal strategies to modify consumer beliefs about an organization. For example, Tybout, Calder, and Sternthal [29] recently demonstrated in a laboratory experiment that false rumors regarding a business' marketing policies can be mitigated using information retrieval and storage strategies.

Finally, the crisis management perspective has concentrated on the importance of organizational planning and managerial responsiveness to crises or disasters. Particular emphasis has been placed recently on the need for all organizations to develop strategic response plans for a variety of disaster scenarios [7] and the importance of managing "aftershocks" that occur following the initial crisis [22].

In summary, these three perspectives suggest that businesses' ability to manage environmental trauma is influenced by factors such as perceptions of the adversaries, communications between the adversaries, information processing by consumers, and managerial preparedness for crises. These three perspectives offer a framework for studying boycotts that is particularly helpful for the development of questions used in the data collection interviews in this study.

\section{Methodology}

To identify consumer boycotts to include in this study, sixteen newspaper and periodical indices were reviewed for their entries under "Boycotts." A boycott was selected if it met all of the following criteria:

1. The boycott was active during the period of January 1,1981 to December 31,1984 . Boycotts prior to 1981 were not included because pretest interviews indicated that respondents encountered recall problems due to the elapsed time.

2. The boycott focused on consumer issues regarding product quality, pricing, promotion policies, distribution arrangements, etc. Boycotts associated with labor strikes were not included because of the problems involved with separating the effects of the boycott and the strike.

3. The boycott was based primarily in the United States or Canada. Language problems and data collection costs prevented consideration of boycotts based in other countries. 
This review yielded 38 reported consumer boycotts which met these selection criteria. Of this set, five boycotts were removed because efforts to identify the current location of the boycotting group were unsuccessful. Also, three more boycotts were dropped because the target managers and boycott leaders indicated that the news media had incorrectly reported the occurrence of a boycott. Thus, 30 identifiable and confirmed boycotts were included in the final set.

Using the factors suggested by the consumerism, consumer information processing, and crisis management perspectives in the conceptual framework, a series of open-ended questions was constructed. These questions were pretested on a set of three labor relations boycotts to ensure content validity. The following questions were included in the final interviewing guide for boycott targets:

1. What were the protesting group's complaints against your organization?

2. What was your attitude toward these complaints?

3. Did you make any of the changes sought by the protesting group?

4. Did the boycott create any problems for your organization?

5. What did the protesting group do to promote the boycott?

6. How did your organization respond to the boycott?

7. What advice would you give to other organizations that become the targets of boycotts?

Probing questions were used to encourage respondents to provide greater detail in their answers to the seven basic questions listed above. The wording of the questions was modified accordingly for the interviews with the boycott leaders.

Efforts were made to conduct telephone interviews with respondents from both the targets of the boycotts and the organizations promoting the boycotts. This is the first research study in the boycott area to obtain information from both parties involved in boycotts. In all interviews, preliminary questions were asked to identify and locate the person in each organization most qualified to answer questions regarding the boycott. The telephone interviews lasted on average approximately 25 minutes. To encourage respondent cooperation and candor, the respondents were guaranteed anonymity.

The interview completion rate was $77 \%$ for boycott targets (23 of 30 ) and $80 \%$ for boycott leaders ( 24 of 30 ). The most common reason given for noncooperation was the lack of time to complete the interview. Given the highly sensitive nature of most boycott situations, this completion rate was encouraging. 


\section{Analysis}

The recent methodological literature regarding business research suggests that qualitative analysis should be employed in the early stages of conceptual development $([3],[6],[15])$. Because this is the first broad-based study to consider the strategies that companies should employ as targets of boycotts, a qualitative analysis was considered the most appropriate approach. The strategic guidelines outlined in Figure 1 and discussed in the remainder of this paper evolve from the qualitative analysis and are illustrated with supporting comments from the interview respondents.

\section{Figure 1}

\section{Strategic Guidelines}

1. Corporate managers must realize that any organization could
be the target of a consumer boycott.
2. Corporate managers should listen attentively to dissatisfied
groups in their environment.
3. Corporate managers should adopt a responsive, non-defensive
posture for legitimate complaints raised by dissatisfied groups.
4. Corporate managers should be prepared to utilize the news
media as a strategic weapon.
Corporate managers should be prepared to rally support
among their constituents.

\section{Strategic Guidelines}

As summarized in Figure 1, five prominent themes emerged in the interviews that are of direct strategic importance to corporate managers who might be confronted with a consumer boycott:

1. Corporate managers must realize that any organization could be the target of a consumer boycott. Many target respondents in this study remarked on the need for all businesses to be aware that they could face a crisis situation if they become the target of a boycott. They advocated that all organizations should adopt contingency response plans even though a consumer boycott may not appear to be imminent. Based on their often harsh experiences, they realized that it is much more difficult to react effectively to a boycott if prior strategic planning has not been prepared:

Any business should not be surprised if this happens to them. First you ask, 'Why us?' And sometimes it defies logic to understand. But you have to be prepared for something like this.

We now have a crisis communications plan in place. We hired a consulting firm.... We now know better how to respond to the 
media in a crisis. Before it was just by the seat of our pants... Every organization should be prepared with crisis planning (for boycotts).

If you are hit by a boycott and you have to turn to someone else for advice, you are in bad shape. You should monitor the environment and be prepared for this.... We were not surprised. We had contingency plans already prepared.

2. Corporate managers should listen attentively to dissatisfied groups in their environment. Every business will at some time institute policies that offend certain groups. If a group of concerned citizens finds that a business practice is offensive to them, they will usually first try to contact the business and express their dissatisfaction. The boycott leaders interviewed for this study often indicated that the only reason they resorted to using a boycott was because the managers of the target companies refused to listen and respond in a timely manner to their complaints:

(A boycott) was our only option. We had tried everything else. We had written to (the company), but they wouldn't listen... We decided enough is enough.

It is not our policy to boycott. We would rather deal with them from a different way. We would rather negotiate and reach a reasonable solution... There was some trouble with communication. They were not listening as well as they should have (to our complaints).

This pivotal role of communication was also recognized by many boycott target managers. They stressed the importance of listening to complaints registered by groups in the environment. Also, beyond this recognition of dissatisfaction, the managers suggested that companies should be willing to explain their positions on these controversial issues so that the disagreement with the concerned group can be resolved or at least minimized:

You have to find out, 'What is their beef?' Then you have to try to deal with it and clean up any miscommunication. See what their problem is before you act. You can defuse a problem by getting information out.

Be sure there is an understanding of views and positions. ... Communication is good as long as there is a sincerity of interest.... There is some risk in communication, but (our company) has maintained an open disclosure policy.

3. Corporate managers should adopt a responsive, non-defensive posture for legitimate complaints raised by dissatisfied groups. Both 
business managers and boycott leaders stated that boycotts can become batthes of egos if corporate leaders respond defensively to complaints. For example, one boycott leader described the intense feelings of corporate management in her dispute:

The chairman (of the company) said, when I was testifying at a hearing (regarding the dispute), 'That is one of the most (expletive deleted) economic statements I ever heard!' He was ready to attack me physically. He had his finger at my nose.

The emotional stress created by boycotts was also acknowledged by some corporate managers:

Don't take (the boycott) personally. Boycotts create a great deal of stress but you cannot afford to take it personally.

When the complaints raised by the concerned group are legitimate, corporate managers should clearly explain how and when they plan to modify these improper practices. The stubborn refusal to alter obviously incorrect corporate policies only invites the imposition of a consumer boycott which may cost the company dearly in the long run, as these managers explained:

Be realistic.... Realize what it may ultimately cost you and then ask yourself if you are willing to pay this price (to defend your policies).

Make sure the company is committed to the business practice that is under attack. If this is a questionable business practice, it is harder to defend against these attacks.

You should never ignore the wishes of your customers. Meet with them to hear their views and to explain your position. If you are wrong, you should beat a hasty retreat.

4. Corporate managers should be prepared to utilize the news media as a strategic weapon. In many situations the company will conclude that the protesting group's complaints are not legitimate and no reasonable compromise is attainable. In these cases the company must pursue defensive strategies that allow the maintenance of these disputed practices while the costs to the company of the consumer boycott are minimized.

When these situations arise, corporate managers who are experienced boycott veterans stressed the importance of conveying the company's position in the media. They stressed that, if the company's views are not transmitted in the media, the boycott organizers will dominate the information the public receives in the dispute and thereby encourage more consumers to join the boycott: 
In the beginning we were quite passive. But after the (boycott) group issued blatant misrepresentations, we became more aggressive in our response. Now, more newspaper editors and consumers are more acceptant of our position.

We had a contingency plan. We knew what our response would be.... We knew which reporters in New York and Washington would cover this dispute... After (the boycott leaders') news conference announcing the boycott, we called up those reporters and offered our views.

Try to be more evident about what you are doing to help the problem (that is the subject of the boycott). We never before bragged about or issued press releases about what we did in these areas. But now we do.

5. Corporate managers should be prepared to rally support among their constituents. Consumer boycotts can generate broad repercussions for the target company. The corporate managers emphasized the importance of sharing information and coordinating boycott strategy with associated business units, such as distributors, retailers, franchisees, suppliers, and advertisers. If the boycott target refuses to share information with its business partners, rumors and misinformation will flourish and compound the target's problems:

Lobby quietly among your members to try to maintain unity.... Quickly respond in a positive way before the psychological pressure of the boycott has a domino effect.

The best thing you can do is to avoid the impulse to not share information with your constituency. Some people here felt we should be selective in disseminating information to our constituency. But I argued that we should present our view.

You need to mobilize your facts to deal with the inaccuracies put out by the other side.... You need to pass along these facts to your local people.

\section{Discussion}

The strategic suggestions offered by the experienced managers were in many respects highly similar to factors suggested by scholars writing in the consumerism, information processing, and crisis management literatures. For example, the managers in this study highlighted the critical importance of organizational preparedness (crisis management perspective), the pivotal role played by effective communication (information processing perspective), and the impact of differing perceptions of reality (consumerism perspective).

However, these managers also brought out other variables that generally have been overlooked in the existing literature. For instance, they placed 
special emphasis on the role of communication with and through the news media, instead of communication just with the immediate group of protesters. Also, they stressed the need to coordinate strategy with constituents, such as channel members, advertisers, and banking institutions.

Because the managerial perspective on boycotts has received little attention, additional research is still required. Based on the results of this study, potential future research topics could include:

1. How do constituents respond when they discover that an organization is the target of a boycott? How can a target organization maximize constituent support and minimize constituent costs during the boycott?

2. What are the most effective tactics for dealing with the news media and maximizing favorable press coverage?

3. Instead of merely listening to complaints raised by dissatisfied groups in the environment, what can organizations do to review and modify business practices before they instigate dissatisfaction? Is the use of consumer advisory panels a sufficient solution?

\section{Conclusion}

Consumer boycotts are environmental forces that cannot be ignored by prudent corporate managers. As stated by the respondents in this study, the failure to develop strategic guidelines for responding to consumer boycotts may cause corporate managers to utilize ineffective and inefficient actions that only exacerbate their problems when they actually face a boycott. However, if a well-conceived strategic response plan is implemented, a potential boycott target may be able to minimize dissatisfaction from consumer groups and, in turn, maximize corporate productivity.

\section{References}

1. Bettman, James R. An Information Processing Theory of Consumer Choice. Reading, MA: Addison-Wesley, 1979.

2. Bloom, Paul N. and Greyser, Stephen A. "The Maturing of Consumerism." Harvard Business Review, November-December 1981, pp. 130139.

3. Bonoma, Thomas V. "Case Research in Marketing: Opportunities, Problems, and a Process." Journal of Marketing Research, vol. 22, May 1985, pp. 199-208.

4. Clark, Kenneth B. Dark Ghetto: Dilemmas of Social Power. New York, NY: Harper \& Row, Publishers, 1965. 
5. DeGrespigny, A.R.C. and McKinnell, R.T. "The Nature and Significance of Economic Boycott." The South African Journal of Economics, vol. 28, no. 4, December 1960, pp. 319-336.

6. Deshpande, Rohit. "Paradigms Lost: On Theory and Method in Research in Marketing." Journal of Marketing, vol. 47, Fall 1983, pp. 101-110.

7. Dilenscheider, R.L. and Hyde, Richard C. "Crisis in Communications: Planning for the Unplanned." Business Horizons, January-February 1985, pp. 35-38.

8. Forbes, James D. "Organizational and Political Dimensions of Consumer Pressure Groups." Journal of Consumer Policy, vol. 8, June 1985, pp. 105-131.

9. Fornell, Claes and Westbrook, Robert A. "The Vicious Circle of Consumer Complaints." Journal of Marketing, vol. 48, Summer 1984, pp. 68-78.

10. Friedman, Monroe. "The 1966 Consumer Protest as Seen by Its Leaders." The Journal of Consumer Affairs, Summer 1971, pp. 1-23.

11. "Consumer Boycotts." Proceedings of the American Council on Consumer Interests, 1982, pp. 96-97.

12.

"Consumer Boycotts in the United States, 1970-1980: Contemporary Events in Historical Perspective." The Journal of Consumer Affairs, vol. 19, Summer 1985, pp. 96-117.

13. Garrett, Dennis E. "Consumer Boycotts: Are Targets Always the Bad Guys?" Business and Society Review, vol. 58, Summer 1986, pp. 17-21.

14. Hines, Ralph H. and Pierce, James E. "Negro Leadership After the Social Crisis: An Analysis of Leadership Changes in Montgomery, Alabama." Phylon, vol. 24, no. 2, Summer 1965, pp. 162-172.

15. Hirschman, Elizabeth C. "Humanistic Inquiry in Marketing Research: Philosophy, Method, and Criteria." Journal of Marketing Research, vol. 23, August 1986, pp. 237-249.

16. Hutt, Michael D., Michael P. Mokwa, and Stanley J. Shapiro. "The Politics of Marketing: Analyzing the Parallel Political Marketplace." Journal of Marketing, vol. 50, January 1986, pp. 40-51.

17. Jackson, Jacquelyne J. "Two Black Boycotts: A Contrast of Success and Failure." Afro-American Studies, vol. 2, September 1971, pp. 87-94.

18. Laidler, Harry W. Boycotts and the Labor Struggle. New York, NY: Russell \& Russell, 1913. 
19. Mahoney, John. "The Relation of Anticipated Effectiveness, Alienation, and Value Structure to Planned Participation in a National Meat Boycott." Psychology, vol. 13, May 1976, pp. 39-47.

20. Miller, Kenneth E. and Sturdivant, Frederick D. "Consumer Responses to Socially Questionable Corporate Behavior: An Empirical Test." Journal of Consumer Research, vol. 4, June 1977, pp. 1-7.

21. Pagan, Rafael D., Jr. "The Nestle Boycott: Implications for Strategic Business Planning." The Journal of Business Strategy, Spring 1986, pp. 12-18.

22. Phelps, Norman L. "Setting Up a Crisis Recovery Plan." The Journal of Business Strategy, Spring 1986, pp. 5-10.

23. Petrof, John V. "The Effect of Student Boycotts Upon the Purchasing Habits of Negro Families in Atlanta, Georgia." Phylon, vol. 24, no. 3, Fall 1963, pp. 266-270.

24. Phillips, W.M., Jr. "The Boycott: A Negro Community in Conflict." Phylon, vol. 22, no. 1, Spring 1961, pp. 24-30.

25. Post, James E. "Assessing the Nestle Boycott: Corporate Accountability and Human Rights." California Management Review, vol. 27, Winter 1985, pp. 113-131.

26. Rea, Samuel A., Jr. "The Economics of a Consumer Boycott." Journal of Economics and Business, vol. 27, no. 1, Fall 1974, pp. 89-92.

27. Resnik, Alan J. and Harmon, Robert R. "Consumer Complaints and Managerial Response: A Holistic Response." Journal of Marketing, vol. 47, Winter 1983, pp. 86-97.

28. Richins, Marsha L. "Negative Word-of-Mouth by Dissatisfied Consumers: A Pilot Study." Journal of Marketing, vol. 47, Winter 1983, pp. 68-78.

29. Tybout, Alice M., Bobby J. Calder, and Brian Sternthal. "Using Information Processing Theory to Design Marketing Strategies." Journal of Marketing Research, vol. 18, February 1981, pp. 73-79.

30. Zeithaml, Carl P. and Zeithaml, Valarie A. "Environmental Management: Revising the Marketing Perspective." Journal of Marketing, vol. 48, Spring 1984, pp. 46-53. 